\title{
TRACE METALS ACCUMULATION IN MOLLUSCAN SHELLS FROM DAMIETTA NILE BRANCH SEDIMENTS, EGYPT
}

\author{
Ibrahim M. Lotfy \\ Institute of Oceano. \& Fish,. Egypt
}

Key words: trace metals, bivalves, gastropods, environmental factors, Damietta Nile branch.

\section{ABSTRACT}

The dissolved heavy metals (As, $\mathrm{Ba}, \mathrm{Cd}, \mathrm{Cr}, \mathrm{Co}, \mathrm{Cu}, \mathrm{Fe}, \mathrm{Mn} . \mathrm{Mo}, \mathrm{Ni}$, $1 \mathrm{~Pb}, \mathrm{Se}, \mathrm{Sr}, \mathrm{V}$ and $\mathrm{Zn}$ ) in molluscan shells from Damietta Nile branch sediments were estimated in three zones during April - June 2004.The average values $\left(\mathrm{ppm} \times 10^{-3}\right)$ were $0.63,0.3,0.01,0.05,0.13,2.32,3.33$, $1.97,0.19,0.22,0.26,0.5,2.51,0.051$ and 2.21 , respectively.

Results indicate that levels of heavy metals increased northwards and in nepionic (recent) stages and were positively correlated with salinity, chlorisity, alkalinity, dissolved oxygen and calcite mineral and negatively correlated with $\mathrm{pH}$ values and aragonite mineral. Certain heavy metals such as $\mathrm{As}, \mathrm{Co}, \mathrm{Cu}, \mathrm{Fe}, \mathrm{Mn}$. $\mathrm{Mo}$ and $\mathrm{Pb}$ were more abundant in bivalve shells(i.e. high aragonite), while $\mathrm{Ba}, \mathrm{Cd}, \mathrm{Cr}, \mathrm{Ni}, \mathrm{Pb}, \mathrm{Sr}, \mathrm{V}$ and $\mathrm{Zn}$ were more abundant in gas'ropod shells (i.e. high calcite).

\section{INTRODUCTION}

Under natural conditions, the most important inputs of metals to aquatic regions are the mechanical weathering of rocks (Bryan, 1984).

There are numerous types of pollutants in the aquatic environment such organic matter, major and trace metals contribute to both natural and anthropogenic sources including storm dust- fall, erosion or crustal weathering and decomposition of biota in water, whereas the anthropogenic sources include sewage, industrial and mobile wastes as shipwrecks and dumping of war materials (Al- Saad 1995; Lotfy 1997; Ansari et al. 1999).

The direct discharge of wastes containing trace metals to the environment, tends to increase in water column, while sediments act as archive for pollutants (Barnes et al., 1984; Barcellos et al., 1988), and may quantitatively and qualitatively after the natural biochemical cycle 
(Grimanis et al., 1978). As a part of the aquatic environment, recent shells accumulate trace metals and act as indicators of pollution (Roy and Crawford, 1984; Kilby and Batley, 1993; Lotfy, 1997, 2000 and 2001).

A few reports of heavy metals concentrations in freshwater molluscan shells have been documented. Several studies on the pollution of molluscan shells by trace metals (Turikian and-Armstrong, 1960; Dodd, 1963; FAO, 1964; Lotfy, 1997, 2000, 2001, 2002 and 2003), were taken into consideration.

The Damietta Nile branch extends north of Al- Kanater Barrage for about $218 \mathrm{~km}$ along the eastern boundary of the Nile Delta Egypt and it leads finally to the Mediterranean Sea after Faraskour dam (Fig. 1). It varies in width from 180 and $250 \mathrm{~m}$. The branch represents a shallow water stream with a depth fluctuating between 4.5 and $16 \mathrm{~m}$. The bottom sediments range from gravelly sand and sand units in the beach and southwards to gravelly muddy sand and muddy sand units in the deep zone and northwards (Lotfy, 1997).

This study aimed to determine the distribution of trace metals in some molluscanan shells to illustrate the relation between their accumulation, metabolism, secondary alteration, environmental parameters and the sources of these pollution.

\section{MATERIALS AND METHODS}

A total of 50 samples were collected from recent bottom sediments, representing the area of Damietta Nile branch and distributed along ten stations (Fig. 1). Each station was represented by five samples (i.e. two from eastern, two from western beach and one from the mid- stream).

The bottom samples were collected by a Peterson dredge grap sampler from different locations during April- June, 2004.

Water samples were collected from different locations in polyethylene bottles using water sampler. Water temperatures were recorded using thermometer. Dissolved oxygen and salinity were determined according the methods described by Strickland and Parsons (1972). The $\mathrm{pH}$ values were measured by a pocket $\mathrm{pH}$ meter. The total alkalinity was determined by titration versus standard $\mathrm{HCl}$, using methyl orange indicator. The total hlorides were determined following Mohr's titration.

Th: shells of the bivalve Anodonta implicata (nepionic and adult stages and the gastropod Bellamiya unicolor (nepionic and adult stages were picked up from Damietta Nile branch sediments. 
The determination of trace metals $\mathrm{As}, \mathrm{Ba}, \mathrm{Cd}, \mathrm{Cr}, \mathrm{Co}, \mathrm{Cu}, \mathrm{Fe}, \mathrm{Mn}$. $\mathrm{Mo}, \mathrm{Ni}, \mathrm{Pb}, \mathrm{Se}, \mathrm{Sr}, \mathrm{V}$ and $\mathrm{Zn}$ in the studied species was done using the Inductivity Coupled Plasma (ICP) in the Central Laboratory for Environmental Quality Monitoring (CLEQM), National Water Research Center, Kanater, Kalyubeya, Egypt.

\section{RESULTS AND DISCUSSION \\ Environmental Parameters of Water}

Table (1)and Fig. ( 2 ) illustrate several important factors concerning the spatial distribution of $\mathrm{pH}$ value, oxygen content, chlorisity, alkalinity in Damietta Nile branch water, and the distribution of carbonate mineral phases of bivalve and gastropod shells in different zones of study area by Lotfy ( 1997 ).

The Damietta Nile branch water temperature was subjected to both diurnal and seasonal variations (Lotfy, 1997). The monthly variation of the water temperature ranged between $14.5^{\circ} \mathrm{C}$ (January) and $32^{\circ} \mathrm{C}$ (June). The $\mathrm{pH}$ values of water ranged from 7.5 at Damietta to Ras El-Bar area to 8.11 at El-Kanater to El-Mansoura; it lies mostly on the alkaline side. The salinity of water concentrated in the Estuary of Damietta ranged between 35 and $42.51 \%$. the content of chlorisity ranged from $40.6 \mathrm{mg} / 1$ at El-Kanater (southern region) to $79.5 \mathrm{mg} / \mathrm{l}$ northwards. Then the high concentration was observed at Damietta Estuary (close to the Mediterranean Sea). The dissolved oxygen varied at different sites and the water was completely oxygenated from surface to bottom. It's content ranged from $7.54 \mathrm{mg} / \mathrm{l}$ at the southern area to $9.51 \mathrm{mg} / \mathrm{l}$ at Damietta Estuary (Fig. 2).Total alkalinity of Nile water attained a highest value northwards with $196.3 \mathrm{mg} / \mathrm{l}$ (Fig. 2), then declined to minimum value southwards with an average of $164.5 \mathrm{mg} / \mathrm{l}$.

Lotfy (1997) proved that the carbonate mineral phases of bivalve and gastropod shells consist mainly of aragonite and calcite. The aragonite decreased northwards, while the calcite increased. In gastropod shells, the maximum value of aragonite was recorded southwards reaching as high as $95 \%$ and the minimum value of aragonite occurred northwards attaining $25 \%$ (Fig. 2 and Table 1), while the calcite ranged between $5 \%$ (southwards) and $75 \%$ (northwards). The aragonite contents in bivalve shells ranged from $95.5 \%$ (southwards) to $75 \%$ (northwards) and the calcite varied between $3.5 \%$ (southwards) and $25 \%$ (northwards). 


\section{Trace Metals in Bivalve Shells}

Concentrations of the trace metals arsenic (As), barium (Ba), cadmium (Cd), chromium ( $\mathrm{Cr})$, cobalt (Co),copper ( $\mathrm{Cu})$, iron $(\mathrm{Fe})$, manganese $(\mathrm{Mn})$, molybdenium $(\mathrm{Mo})$, nickel $(\mathrm{Ni})$, lead $(\mathrm{Pb})$, selenium (Se), strontium ( $\mathrm{Sr}$ ), vanadium (V) and zinc ( $\mathrm{Zn}$ ) in the bivalve Anodonta implicata shell are listed in Table (2) and presented in Fig. (3). For As, $\mathrm{Ba}, \mathrm{Cd}, \mathrm{Cr}$ and $\mathrm{Co}$, the mean levels due to Anodonta implicate shells ranged between $0.61-1.33,0.04-0.31,0.001-0.013,0.02-0.096$ and $0.01-0.075 \mathrm{ppm} \times 10^{-3}$, respectively. In the northern zone (close to the Damietta city), the average contents of As and Cd. showed a high content in nepionic stage, while $\mathrm{Ba}$ in the adult stage. In the southern region (near to the industrial region in Cairo), $\mathrm{Co}$ and $\mathrm{Cr}$ showed maximum values in nepionic stage. Meanwhile, the minimum values of $\mathrm{As}, \mathrm{Ba}$ and $\mathrm{Cd}$ appeared in southern zone in adult stage, and the lowest value of $\mathrm{Co}$ showed in nepionic stage (northwards). Finally, the lowest value of $\mathrm{Cr}$ was recorded in mid-stream in the adult stage.

According to the distribution of $\mathrm{Cu}, \mathrm{Fe}, \mathrm{Mn}, \mathrm{Mo}$ and Ni (Table 2 and Fig. 3), the northern zone showed a maximum values of $\mathrm{Cu}, \mathrm{Fe}, \mathrm{Mn}$ and $\mathrm{Mo}$ in nepionic stage and $\mathrm{Ni}$ in the adult stage $(7.71,5.99,3.41,0.5$ and $0.09 \mathrm{ppm} \times 10^{-3}$, respectively). Towards the southern region, the values of $\mathrm{Cu}, \mathrm{Mn}$, Mo and $\mathrm{Ni}$ became very low $(0.16,0.98,0.12$ and 0.018 ppm $\times 10^{-3}$, raspectively) in the adult stage, while the lowest value of $\mathrm{Fe}$ $\left(0.78 \mathrm{ppm} \times 10^{-3}\right)$ was recorded in the adult stage (northwards).

Generally, the trace metal levels in Anodonta implicata shells were more abundant in nepionic stage (northwards).

As shown in Table (2) and Fig. (3), the levels of $\mathrm{Pb}, \mathrm{Se}, \mathrm{Sr}, \mathrm{V}$ and $\mathrm{Zn}$ ranged between $0.19-0.61,0.18-0.87,0.16-1.5,0.017-0.09$ and 0.52 $2.68 \mathrm{ppm} \times 10^{-3}$, respectively. Changes in total levels of $\mathrm{Pb}, \mathrm{Se}, \mathrm{Sr}$ and $\mathrm{Zn}$ in Anodonta implicate shells from Damietta Nile branch sediments attained the highest level in nepionic stage in northern area with 0.61 , $0.87,1.5$ and $2.68 \mathrm{ppm} \times 10^{-3}$, respectively, while the highest value of $\mathrm{V}$ was attained in the adult stage (rorthwards) with $0.09 \mathrm{ppm} \times 10^{-3}$. Their levels became very low in adult stage southwards.

Enrichment Factors(E.F.) for the accumulation of trace metals in the 'ifferent stages of bivalve shells can be derived using the following expressi jn:

\begin{tabular}{|l|l|}
\hline E.F. $=$ & mean concentration of trace metals in the nepionic stage \\
\hline mean concentration of trace metals in hie adult stage \\
\hline
\end{tabular}


From Table (4) with the exception of the southern sector( close to the industrial region at Greater Cairo), the E.F. for As $\mathrm{Ba}, \mathrm{Cd} \mathrm{ro}, \mathrm{Cr}$. $\mathrm{Cu}, \mathrm{Fe}, \mathrm{Mn}, \mathrm{Mo}, \mathrm{Ni}, \mathrm{Pb}, \mathrm{Se}, \mathrm{Sr}, \mathrm{V}$ and $\mathrm{Zn}$ were greater than $1.1,7,9,1.25$, $5.29,43,6.28,1.57,1.33,4.33,3.05,4.67,4.25,4$, and 4.64 , respectively. These factors indicated that the nepionic stage of bivalve shells were more highly polluted southwards (i.e. highly correlated with aragonite content).

Meanwhile, in the middle sector( close to El-Mansoura city), the E.F. for $\mathrm{As}, \mathrm{Ba}, \mathrm{Cd}, \mathrm{Cr}, \mathrm{Cu}, \mathrm{Fe}, \mathrm{Mn}, \mathrm{Mo}, \mathrm{Pb}, \mathrm{Se}$, and $\mathrm{Zn}$ were greater than $1.17,1.14,6,5,32.4,1.25,2.21,2.05,2.62,1.21$ and 1.45 , respectively, while $\mathrm{Co}, \mathrm{Ni}$ and $\mathrm{V}$ levels exhibited low enrichment in nepionic stage.

Finally, in the northern sector (near to Damietta city), the E,F, for As, $\mathrm{Ba}, \mathrm{Cd}, \mathrm{Cr}, \mathrm{Cu}, \mathrm{Fe}, \mathrm{Mn}, \mathrm{Mo}, \mathrm{Pb}, \mathrm{Se}, \mathrm{Sr}$ and $\mathrm{V}$ contents were greater than $1.08,4.33,3.5,8.04,7.68,1.54,2.38,2.18,2.72,1.44$ and 1.04, respectively, while $\mathrm{Ba}, \mathrm{Co}, \mathrm{Ni}$ and $\mathrm{V}$ values in nepionic stage exhibited low enrichment.

\section{Trace Metals in Gastropod Shells}

Leveis of trace metals $\mathrm{As}, \mathrm{Ba}, \mathrm{Cd}, \mathrm{Co}, \mathrm{Cr}, \mathrm{Cu}, \mathrm{Fe}, \mathrm{Mn}, \mathrm{Mo}, \mathrm{Ni}, \mathrm{Pb}$, $\mathrm{Se}, \mathrm{Sr}, \mathrm{V}$ and $\mathrm{Zn}$ in the gastropod Bellamiya unicolor shell are listed in Table (3) and presented in Fig. (4). Appreciable difference could be observed in the abundance of the elements in all stations and in nepionic and adult stages with relatively high levels for most metals at northern region. Their levels ranged between $0.16-0.6,0.26-0.63,0.01-0.019$, $0.013-0.04,0.018-0.56,0.12-1.8,0.88-5.7,1.58-2.28,0.08-0.19$, $0.004-1.04,0.12-0.23,0.08-1.3,0.03-0.36,1.48-6.9,0.018-0.16$, and 0.94- $3.28 \mathrm{ppm} \times 10^{-3}$, respectively.

Concerning the distribution of $\mathrm{As}, \mathrm{Ba}, \mathrm{Cd}, \mathrm{Co}$ and $\mathrm{Cr}$ (Fig. 4), the highest levels of $\mathrm{As}, \mathrm{Ba}$ and $\mathrm{Cr}$ were attained in the northern side in nepionic stage, while $\mathrm{Co}$ in the adult stage, finally the highest value of $\mathrm{Cd}$ occurred in the southern region in nepionic stage. Generally, their levels were less abundant in southern zone, while $\mathrm{Cd}$ value decreased northwards.

However, the gradient of $\mathrm{Cu}, \mathrm{Fe}, \mathrm{Mn}, \mathrm{Mo}$ and $\mathrm{Ni}$ levels variation in Bellamiya unicolor shells are shown in Fig. 4. The maximum value of $\mathrm{Cu}$, Fe and Mo (1.8, 5.7 and $0.19 \mathrm{ppm} \times 10^{-3}$, respectively) was observed in adult stage (northwards), while $\mathrm{Ni}$ reached a highest level (2.28 $\mathrm{ppm} \times 10^{-3}$ ) in nepionic stage (southwards).

Levels of $\mathrm{Pb}, \mathrm{Se}, \mathrm{Sr}, \mathrm{V}$ and $\mathrm{Zn}$ in shells of Bellamiya unicolor showed a general increase northwards, where high levels of $\mathrm{Pb}, \mathrm{Sr}$ and $\mathrm{Zn}$ 
(0.23, 6.9 and $3.28 \mathrm{ppm} \times 10^{-3}$, respectively) were recorded in nepionic stage, while high values of $\mathrm{Se}$ and $\mathrm{V}$ (1.3 and $0.16 \mathrm{ppm} \times 10^{-3}$, respectively) were measured in adult stage and decreased southwards, while Se decreased towards the middle zone.

From Table (4), with the exception of the southern sector, the E.F. for $\mathrm{Ba}, \mathrm{Cd}, \mathrm{Cr}, \mathrm{Mn}, \mathrm{Ni}, \mathrm{Pb}, \mathrm{Sr}$ and $\mathrm{Zn}$ in gastropod shells were greater than $1.46,1.46,7.78,1.44,5.68,1.11,5.33$ and 2.68 , respectively, while As, $\mathrm{Co}, \mathrm{Cu}, \mathrm{Mo}, \mathrm{Se}$ and $\mathrm{V}$ exhibited low enrichment in nepionic stage.

In the mid- stream region, most of elements exhibited high values, while $\mathrm{Co}, \mathrm{Cu}, \mathrm{Fe}, \mathrm{Mo}$, Se and $\mathrm{V}$ exhibited low values in nepionic stage.

From Table (4), in northern sector, the E.F. for $\mathrm{As}, \mathrm{Ba}, \mathrm{Cr}, \mathrm{Mn}, \mathrm{Ni}, \mathrm{Pb}$, Se and $\mathrm{Zn}$ were greater than $2.4,1.91,2.67,1.15,1.16,1.1,1.92$ and 1.3, while $\mathrm{Cd}, \mathrm{Co}, \mathrm{Cu}, \mathrm{Fe}, \mathrm{Mo}$, Se and $\mathrm{V}$ exhibited low value. generally, most of elements in the gastropod shells are more abundant in nepionic stage (southwards).

The relative order of abundance of elements in the molluscan shells was as follows: $\mathrm{As}, \mathrm{Coco}, \mathrm{Fe}, \mathrm{Mn}, \mathrm{Mo}$ and $\mathrm{Pb}$ that were more associated in bivalve shells, while $\mathrm{Ba}, \mathrm{Cd}, \mathrm{Cr}, \mathrm{Ni}, \mathrm{Sr}, \mathrm{V}$ and $\mathrm{Zn}$ were more associated in gastropod shells, and $\mathrm{Se}$ have a uniform distribution in molluscan shells.

\section{Trace Metals Distribution and Environmental Factors}

From Figs. (2, 3 and 4); the relationship matrix among trace metals levels in molluscan shells and minerals composition of shells and environmental parameters of water demonastrates the following: the combined values show strong pathetic and antipathetic relations; chlorisity, dissolved oxygen, alkalinity , salinity, calcite, most of elements in bivalve shells (except $\mathrm{Co}, \mathrm{Fe}$ and $\mathrm{V}$ ) and all elements in gastropod shells were positively correlated with each other and increased northwards and conversely, they exhibited negative relationships with $\mathrm{pH}$ value, aragonite and $\mathrm{Co}$ in bivalve shells, while $\mathrm{Fe}$ and $\mathrm{V}$ had a uniform distribution in all zones. So, most of elements in molluscan shells except $\mathrm{Co}, \mathrm{Fe}$ and $\mathrm{V}$.were more associated with calcite mineral, while Co were more associated with aragonite. This depends on metabolism, activity of organism, early diagenesis and environmental factors.

Thus, as expected most of trace metals are incorporated into carbonate mineral phases (Batley, 1987; Fernades, 1997; lotfy, 1997, 2000, 2001, 2002 and 2003).

The relative order of abundance of elements in the bivalve shells was as follows: $\mathrm{Cu}>\mathrm{Fe}>\mathrm{Zn}>\mathrm{Mn}>\mathrm{As}>\mathrm{Sr}>\mathrm{Se}>\mathrm{Pb}>\mathrm{Mo}>\mathrm{Ba}>\mathrm{Co}>\mathrm{Ni}>\mathrm{V}>$ 
$\mathrm{Cr}>\mathrm{Cd}$ and most of trace metals increased northwards. In the gastropod shells, their abundance was as follows: $\mathrm{Sr}>\mathrm{Fe}>\mathrm{Zn}>\mathrm{Mn}>\mathrm{Cu}>\mathrm{Se}>\mathrm{Ni}>$ $\mathrm{Ba}>\mathrm{As}>\mathrm{Cr}>\mathrm{Pb}>\mathrm{Mo}>\mathrm{V}>\mathrm{Co}>\mathrm{Cd}$ and all elements increase northwards.

The results also proved that $\mathrm{As}, \mathrm{Co}, \mathrm{Cu}, \mathrm{Fe}, \mathrm{Mn}$ and $\mathrm{Pb}$ are more abundant in bivalve shells, while $\mathrm{Ba}, \mathrm{Cd}, \mathrm{Cr}, \mathrm{Ni}, \mathrm{Sr}, \mathrm{V}$ and $\mathrm{Zn}$ are more abundant in gastropod shells, but $\mathrm{Se}$ has a uniform distribution.

The zonal distribution of trace metals in molluscan shells by using E.F. proved that most elements exhibited high enrichment in nepionic stage northwards and southwards. Then, the main source of pollution is the industrial region in greater Cairo and Damietta cities.

Matching the average values of elements in molluscan shells in Damietta Nile branch sediments with those in carbonate sediments (Turikian and Wedepohl,1961), the results showed that Se is highly enriched in the molluscan shells of Damietta Nile branch. In comparison with the standard shale (Krauskopf and Bird, 1995), results showed that the elements are lowly enriched in the molluscan shells.

Forestner and Muller (1973), Forestner and Wittman (1981) and Forestner (1982) proved that the remobilization of metals from sediments is mainly controlled by the absorbed processes and is mostly caused by four types of chemical changes in water: 1- elevated salt contents; 2changes in the redox; 3 - lowering $\mathrm{pH}$ and 4- presence of natural complexion agents, in addition to biochemical processes and activity of organisms.

\section{CONCLUSION}

Molluscan shells from Damietta Nile branch sediments are slightly contaminated with heavy metals. In spite of the high concentrations recorded in the northern and southern sector, they do not exceed the International permissible concentrations in carbonate sediments and shale.

From the results obtained, the northern sector was slightly polluted with trace metals due to the effect of the Damietta city wastes, followed by southern sector which is close to the greater Cairo, while in the middle sector, the concentrations of heavy metals in the molluscan shells showed lower values.

The relative order of abundance of elements in the bivalve shells was as follows: $\mathrm{Cu}>\mathrm{Fe}>\mathrm{Zn}>\mathrm{Mn}>\mathrm{As}>\mathrm{Sr}>\mathrm{Se}>\mathrm{Pb}>\mathrm{Mo}>\mathrm{Ba}>\mathrm{Co}>\mathrm{Ni}>\mathrm{V}>$ $\mathrm{Cr}>\mathrm{Cd}$ and most of trace metals increased northwards. In the gastropod shells, their abundance was as follows: $\mathrm{Sr}>\mathrm{Fe}>\mathrm{Zn}>\mathrm{Mn}>\mathrm{Cu}>\mathrm{Se}>\mathrm{Ni}>$ $\mathrm{Ba}>\mathrm{As}>\mathrm{Cr}>\mathrm{Pb}>\mathrm{Mo}>\mathrm{V}>\mathrm{Co}>\mathrm{Cd}$ and all elements increased northwards. 
The results proved that $\mathrm{As}, \mathrm{Co}, \mathrm{Cu}, \mathrm{Fe}, \mathrm{Mn}$ and $\mathrm{Pb}$ are more abundant in bivalve shells, while $\mathrm{Ba}, \mathrm{Cd}, \mathrm{Cr}, \mathrm{Ni}, \mathrm{Sr}, \mathrm{V}$ and $\mathrm{Zn}$ are more abundant in gastropod shells, but Se has a uniform distribution.

The trace metals distribution in adult and nepionic stages and by depending on the recorded E.F., most elements in bivalve and gastropod shells were more associated with nepionic stage north- and southwards.

The distribution of trace metals in the recent molluscan shells is mainly controlled by some factors as; elevated salt, increasing alkalinity, chlorosity, dissolved oxygen, transformation of aragonite to calcite and lowering $\mathrm{pH}$ tend to increasing the absorption processes of elements, in addition to activity of organism and metabolism (I.e. trace metals are more associated in gastropod shells).

\section{REFERENCES}

Al- Saad, H.I. (1995). Distribution and sources of hydrocarbon in ShatAl- Arab estuary and NW Arabian Grilf. Ph. D. Thesis, Univ. Barsrah.

Ansari, A.A.; Singh, I.B. and Tobschell H.J. (1999). Status of anthropogenically. induced metal pollution in the Kanpur- Unnao industrial region of the Ganga plain, Indiaa. Envir. Geol. , 38: 25-33.

Barnes, D.; Forster C.F. and Hrudley S.E. (1984). Surveys in industrial waste water treatment. Food and Allied Industries, Pitman, London, 1 .

Barcellos, C.D.C.; Fernandes H.M. and Azevedo H.L.P. (1988). The role of the Aproio Pavuna river in the transport of particulate heavy metals to Jacarepageua lagoon, Brazil. Sci. Total Environ., 75:211- 223 .

Batley, G.E. (1987). Heavy metal speciation in waters, sediments and biota from lake Macquarie, New South Wales. Austr. J. Mari. \& Freshwater Res., 38: 591- 606.

Bourg, A.C.M. (1988). Metals in aquatic and terrestrial systems: sorption, speciation and mobilization. Chem. And Biolo. Of Solid Waste, Dredged Material and Mine Tailings, Springer Verlag, Berlin: 3- 32 . 
Bryan, G.W. (1984). Chapter 3: In; Kinne O, ed. (pollution due to heavy metals and their compounds). Marine Ecology Willey- Inter Science Publ., N. Y., USA, V. 5.

Chenhall, B.E.; Batley, G.E.; Yassini, I.; Depers, A.M. and Jones, B.G. (1994). Ash distribution and metal content of lake Illawarra bottom sediments, Australia. J. Mari.\& Freshwater Res, 45:967292.

Datta, D.K. and Subramanian, V. ( 1997 ).texture and mineralogy of the sediments from the Bengal basin, Bangladesh and their environmental implications. Environ. Geol., 30 (3/4): $181-188$.

Datta, D.K. and Subramanian, V. (1998). Distribution and fractionation of heavy metais in the surface sediments of the GongesBrahmaputra Meghna river system in the Bengal basin. Environ. Geol., $36(1 / 2)$ : 93- 101.

Dodd, J.R. (1963). Environmentally controlled $\mathrm{Sr}$ and $\mathrm{Mg}$ variation in Mytilus. Geo. Soc. Progr. Ann. Mecting Astract Geo. Soc. Amre. Spe. Papers, 76: 46.

FAO, (1994). Review of pollution in the African aquatic environment (CIFA). Technical papers, 25.

Fernandes, H.M. (1997). Heavy metals distribution in sediments and ecological risk assessment: the role of diagenic processes in reducing metal toxicity in bottom sediments, Envir. Pollut., 93:317- 325 .

Forstner, U.(1982). Accumulative phases of heavy metals in limnic sediments. Hydrobiologia, 91: 269- 284.

Forstner, U. and Wittman, G.T.W. (1981): Metal pollution in the aquatic environment. Springer Verlag. Berlin,486pp.

Forstner, U. and Muller, G. (1973). Heavy metal accumulation in river sediments: a response to environmental pollution. Geoforom., 145: 53- 61 . 
Grimanis, A.P.; Zafiroponius, D. and Erimanis, V. (1978). Trace elements in the fish and liver of two fish species from polluted and unpolluted areas of the Aegean Sea. Res. Environ. Sci. Tech., 12: 723- 726.

Kilby, G.W. and Batley, G.E.(1993): Chemical indicators of sediment chronology. Austr. J. Mari. \& Freshwater Res., 44:635- 647.

Krauskopf, K.B. and Bird, D.K. (1995). Introduction to geochemistry. Mc Graw-Hill, Inc. New York, $3^{\text {td }} \mathrm{ed}$., 647pp.

Lotfy, I.M.H. (1997). Mineralogical and geochemical studies of some recent molluscanan shells from lake Qarun sediments, Egypt. Delta J. Sci., 2I(I): 50- 73.

Lotfy, I.M.H. (2000). Mineralogical and geochemical study on recent mollusk shells from Lake Manzalah sediments, Egypt. Delta J. Sci., 24: 87\% 104.

Lotfy, I.M.H. (2002). Mineralogical studies and trace metals in four recent molluscanan shells from Rosetta Nile branch sediments, Egypt. Bull. Nat. Inst. Oceanogr. \& Fish., ARE, 28: 349- 366.

Lotfy, I.M.H. (2003). Mineralogical and geochemical studies on four recent molluscanan shells from Hypersalline Bardawil lagoon sediments, Egypt. J. Egypt Acad. Soc. Environ. Develop., 4(2): 199- 218.

Roy, P.S. and Crawford, E.A. (1984). Heavy metals in a contaminated Australian estusry- dispersion and accumulation trend. Estuarine, Coastal and shelf Sci., 19: 341- 358.

Strickland, J.D.H. and Parsons, T.R. (1972). A practical handbook of sea water analysis. Fish. Res. Publ. Canada, 167, $2^{\text {nd }}$ ed., 310pp.

Turikian, K.K. and Armstrong, K.L. (1960). $\mathrm{Mg}, \mathrm{Sr}$ and $\mathrm{Ba}$ concentrations and calcite, aragonite ratios of some molluscanan shells. J. Marine Res., 18: 133.

Turikian, K.K. and Wedepohl, K.H. (1961). Distribution of the elements in some major units of the Earths Crust. Geol. Soc. Am. Bull., 72: $175-192$. 
Table(1): The recorded average measurements of some mineralogical and chemical environmental parameters in water and carbonate phases of A-bivalve B-gastropod shells from Damietta Nile branch.

\begin{tabular}{|c|c|c|c|c|c|c|c|}
\hline \multicolumn{4}{|c|}{ Sediment } & \multicolumn{3}{c|}{- I-- } & \multicolumn{2}{c|}{ water } \\
\hline zone & \multicolumn{2}{|c|}{ Aragonite\% } & \multicolumn{2}{c|}{ Calcite\% } & pH & Alkal. & chlorosity \\
& A & B & A & B & & Mg/1 & Mg/1 \\
\hline South & 96.5 & 95 & 3.5 & 5 & 8.23 & 164.5 & 40.6 \\
& & & & & & & \\
\hline Middle & 97 & 91 & 3 & 9 & 8.11 & 190.3 & 60.33 \\
& & & & & & - & \\
\hline north & 75 & 25 & 25 & 75 & 7.5 & 196.3 & 79.5 \\
\hline
\end{tabular}

Table(2): Average concentration of trace metals $\left(\mathrm{ppm} \times 10^{-3}\right)$ in shells of Anodonta implicata(bivalve $\mathrm{A}=$ adult, $\mathrm{B}=$ nepionic).

\begin{tabular}{|c|c|c|c|c|c|c|c|c|c|c|c|c|c|c|c|c|}
\hline zone & $*$ & As & $\mathrm{Ba}$ & $\mathrm{Cd}$ & $\mathrm{Co}_{0}$ & $\mathrm{Cr}_{\mathrm{r}}$ & $\mathrm{Cu}$ & $\mathrm{Fe}$ & $\mathrm{Mn}$ & Mo & $\mathrm{Ni}$ & $\mathrm{Pb}$ & Se & $\mathrm{Sr}$ & $\mathrm{v}$ & $\mathrm{Zn}$ \\
\hline \multirow{3}{*}{ south } & $\overline{\mathrm{A}}$ & .62 & .04 & .078 & .08 & .01 & .16 & .92 & .98 & .12 & .02 & .19 & .18 & .16 & .02 & .52 \\
\hline & B & .68 & .28 & .009 & .1 & .07 & 6.88 & 5.8 & 1.5 & .16 & .08 & .58 & .84 & .68 & .07 & 2.3 \\
\hline & Ave & .65 & .16 & .005 & .09 & .04 & 3.52 & 3.5 & 1.3 & .14 & .05 & .18 & .51 & .42 & .04 & 1.6 \\
\hline \multirow[t]{3}{*}{ Mid. } & $\mathrm{A}$ & .92 & .22 & .002 & .08 & .01 & .22 & .81 & 1.7 & .14 & .07 & .22 & 21 & .99 & .06 & 1.7 \\
\hline & $\mathrm{B}$ & 1.08 & .25 & .012 & .07 & .05 & 7.12 & 5.8 & 2.1 & .31 & .05 & 45 & .55 & 1.2 & .03 & 2.5 \\
\hline & Ave & 1 & .24 & .007 & .08 & .03 & 3.67 & 3.3 & 1.9 & .23 & .06 & .34 & .38 & 1.1 & .05 & 2.1 \\
\hline \multirow[t]{5}{*}{ north } & $\mathrm{A}$ & 1.23 & .32 & .003 & .09 & .02 & .33 & .78 & 2.2 & .21 & .09 & .28 & .32 & 1.1 & .09 & 2.6 \\
\hline & $\mathrm{B}$ & 1.33 & .16 & .013 & .02 & .07 & 7.71 & 6 & 3.4 & .5 & .02 & .61 & .87 & 1.5 & .01 & 2.7 \\
\hline & Ave & 1.28 & 24 & .008 & .07 & .05 & 4.02 & 3.4 & 2.8 & .37 & .05 & 45 & .6 & 1.3 & .05 & 2.7 \\
\hline & Tot. & .98 & .21 & .007 & .08 & .04 & 3.74 & 3.4 & 2 & .25 & .05 & .32 & .5 & .93 & .05 & 2.6 \\
\hline & & & 10 & - & .1 & 11 & 4 & & 110 & .4 & 20 & 9 & .1 & 610 & 20 & 20 \\
\hline$* * *$ & & 130 & 580 & .3 & 19 & 90 & 45 & 472 & 850 & 2.6 & 68 & 20 & .4 & 300 & 130 & 95 \\
\hline
\end{tabular}


Table(3): Average concentration of trace metals $\left(\mathrm{ppm} \times 10^{-3}\right)$ in the gastropod shells of Bellamiya unicolor $(\mathrm{C}=$ adult, $\mathrm{D}=$ nepionic).

\begin{tabular}{|c|c|c|c|c|c|c|c|c|c|c|c|c|c|c|c|c|}
\hline$\pi \pi^{\circ}$ & 7 & As & $\mathrm{Ba}$ & Cd & $\mathrm{Co}_{0}$ & $\mathrm{Cr}$ & $\mathrm{Cu}$ & $\mathrm{Fe}$ & Min & Mo & $\mathrm{Ni}$ & $P B$ & Se & $\mathrm{Sr}$ & $\mathbf{V}$ & $Z_{n}$ \\
\hline \multirow[t]{3}{*}{ scith } & c & .18 & .26 & .013 & .014 & .018 & .19 & 3.42 & 1.58 & .31 & .019 & .18 & .18 & .148 & .03 & .94 \\
\hline & D & .16 & 38 & .019 & .012 & .014 & .12 & .88 & 2.28 & .08 & .108 & .2 & .11 & 5.33 & .02 & 2.7 \\
\hline & Ave & .17 & .32 & .016 & .013 & .08 & .15 & 2.15 & 1.93 & .1 & .064 & .19 & .15 & 3.41 & .02 & 1.8 \\
\hline \multirow[t]{3}{*}{ Mid. } & $C^{\prime}$ & .2 & 28 & .012 & .03 & .08 & 13 & 4.11 & 1.68 & .13 & .06 & .12 & .2 & 2.08 & .03 & 1.7 \\
\hline & $\overline{\mathbf{D}}$ & .3 & .41 & .015 & .018 & .21 & .9 & 2.08 & 2.II & .69 & .31 & .17 & .08 & 5.05 & .02 & 2.7 \\
\hline & Avo & .25 & .35 & .014 & .024 & .15 & 1.1 & 3.1 & 1.9 & .11 & .19 & .15 & .14 & 3.57 & .03 & 2.3 \\
\hline \multirow[t]{3}{*}{ north } & $\bar{c}$ & .25 & .33 & .01 & .04 & .21 & 1.8 & 5.7 & 1.81 & .19 & .9 & .21 & 1.3 & 3.6 & .16 & 2.5 \\
\hline & $\overline{\mathbf{D}}$ & .6 & .63 & .009 & .022 & .56 & 1.12 & 3.61 & 2.08 & .11 & 1.04 & .23 & I.I & 6.9 & .07 & 3,3 \\
\hline & $\begin{array}{l}\text { Ave } \\
\text { Tot. }\end{array}$ & $\begin{array}{l}.43 \\
.28\end{array}$ & $\begin{array}{l}.48 \\
.38\end{array}$ & .01 & $\begin{array}{l}.031 \\
.023\end{array}$ & $\begin{array}{l}.39 \\
.21\end{array}$ & $\begin{array}{c}1.46 \\
.9\end{array}$ & $\begin{array}{c}4.66 \\
3.3\end{array}$ & $\begin{array}{l}1.95 \\
1.93\end{array}$ & $\begin{array}{l}.15 \\
.12\end{array}$ & $\begin{array}{l}.97 \\
.39\end{array}$ & $\begin{array}{l}.22 \\
.19\end{array}$ & $\begin{array}{l}1.2 \\
.5\end{array}$ & $\begin{array}{l}5.25 \\
4.08\end{array}$ & .12 & $\begin{array}{l}2.9 \\
2.3\end{array}$ \\
\hline$\cdots$ & & & 10 & $\cdot$ & .1 & II & 4 & - & 110 & .4 & 20 & 9 & .1 & 610 & 20 & 20 \\
\hline 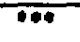 & & 130 & 580 & .3 & 19 & 90 & 45 & 47200 & 850 & 2.6 & 68 & 20 & .4 & 300 & 130 & 95 \\
\hline
\end{tabular}

$*=$ Type of shells $* *=$ Standard of carbonate (Turkian and Wedepohl.,1961) all value $\times 10^{-3} * * *=$ Standard shale (Krauskopt and Bird, 1995) all value $\times 10^{-3}$

Table(4): Enrichment factors of trace metals in nepionic / adult stage of A-bivalve and B- gastropod shells.

\begin{tabular}{|c|c|c|c|c|c|c|c|c|c|c|c|c|c|c|c|c|}
\hline 2000 & 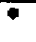 & As & Ba & Cd & $C_{0}$ & $\overline{C r}$ & $\mathrm{Cu}$ & $\mathrm{Fe}$ & $\mathrm{Mn}$ & Mo & $\overline{\mathrm{Ni}}$ & $\mathbf{P b}$ & $\mathrm{Se}$ & $\overline{\mathbf{S r}}$ & $\bar{v}$ & $\mathrm{Zn}$ \\
\hline \multirow{2}{*}{$\begin{array}{c}\text { soulh } \\
.\end{array}$} & $\bar{A}$ & 1.1 & 7 & 9 & 1.23 & 5.29 & 4.3 & 6.28 & 1.5 & 1.33 & 4.33 & 3.05 & 4.67 & 4.25 & 4 & 4.94 \\
\hline & B & .89 & 1.46 & 1.46 & .96 & 7.78 & .63 & .26 & 1.44 & .73 & 5.68 & 1.11 & .61 & 3.6 & .67 & 2.85 \\
\hline \multirow[t]{2}{*}{ Mrd, } & A & 1.17 & 1.14 & 6 & .89 & 5 & 3.4 & 7.2 & 1.25 & 2.21 & .73 & 2.05 & 2.62 & 1.21 & .05 & 1.45 \\
\hline & $\mathrm{B}$ & 1.5 & 1.46 & 1.25 & .06 & 2.63 & .69 & $.5 t$ & 1.26 & .69 & 5.17 & 1.42 & .4 & 2.43 & .67 & 1.74 \\
\hline north & A. & 1.08 & .52 & 4.33 & .22 & 3.5 & 8.04 & 7.68 & 1.54 & 2.38 & .22 & 2.18 & 2.72 & 1.44 & .08 & 1.04 \\
\hline \multicolumn{2}{|c|}{ B } & 2.4 & $1.9]$ & .9 & .55 & 2.67 & .62 & .63 & 1.15 & .58 & 1.16 & I.I & .85 & 1.92 & .44 & 1.3 \\
\hline
\end{tabular}




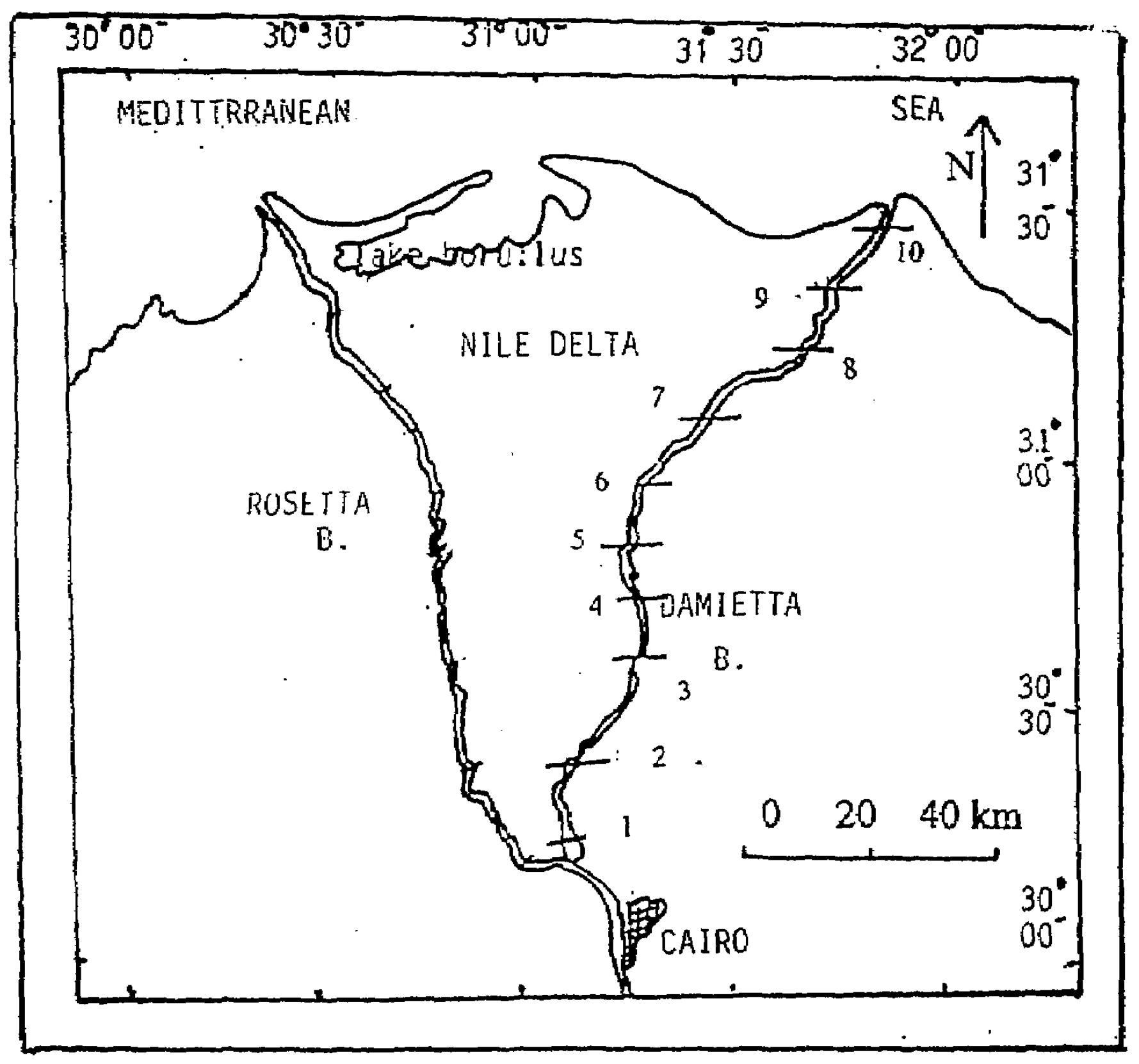

Fig . (1): The Damietta Nile branch map showing sampling locations 
Figure(2): The zonal distribution of environmental parameters of Damietta Nile branch molluscan shells and water( aragonite\%, calcite\%, chlorosity $\mathrm{mg} /$, alkalinity $\mathrm{mg} / \mathrm{l}$ and $\mathrm{pH}$ value) A-bivalve B-gastropod
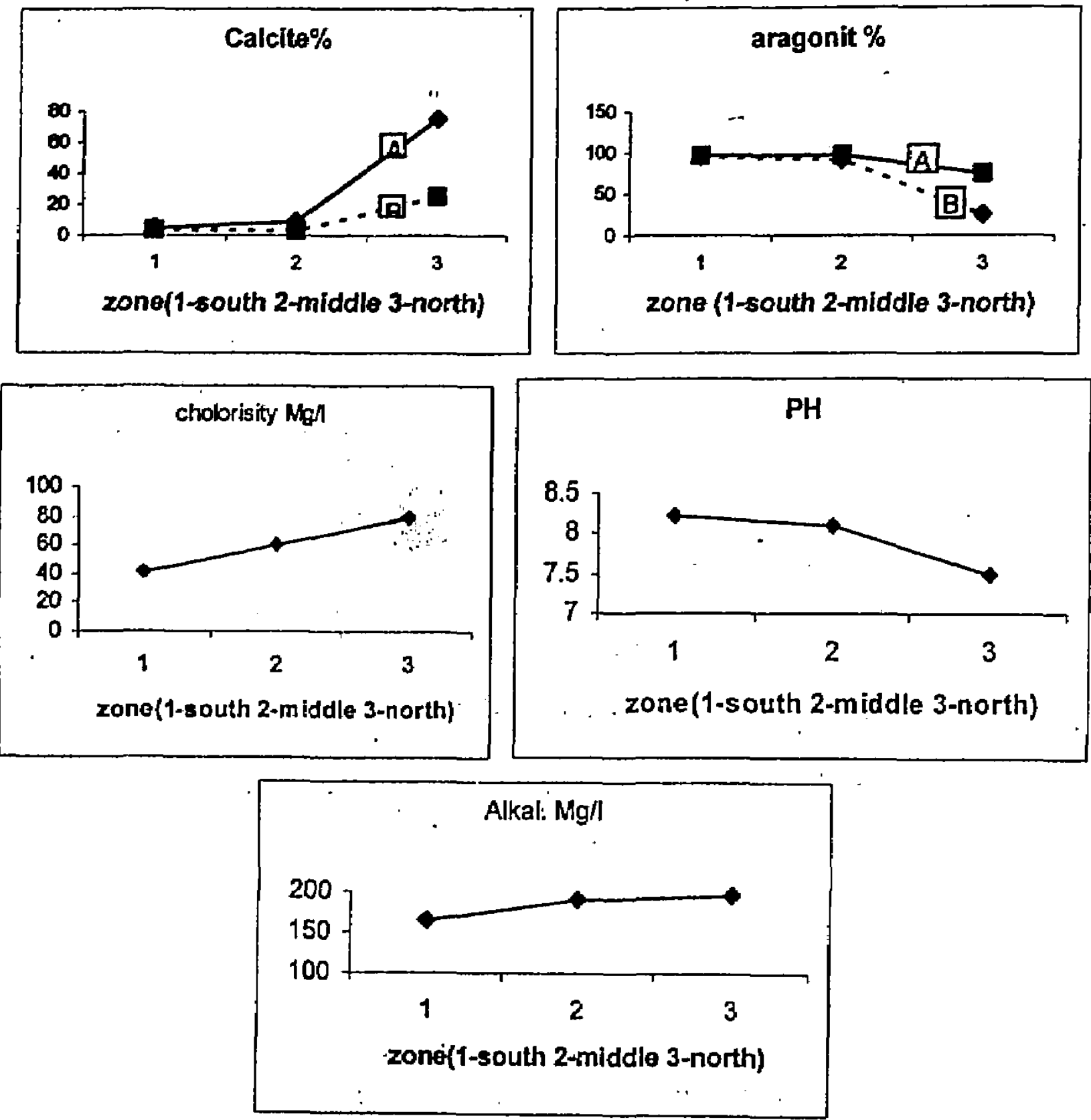
Figure(3): Zonal average distribution of trace metals $\left(\mathrm{ppm} \times 10^{-3}\right)$ in the studied shells of Anodonta implicata (bivalve $\mathrm{A}=$ adult, $\mathrm{B}=$ nepionic).
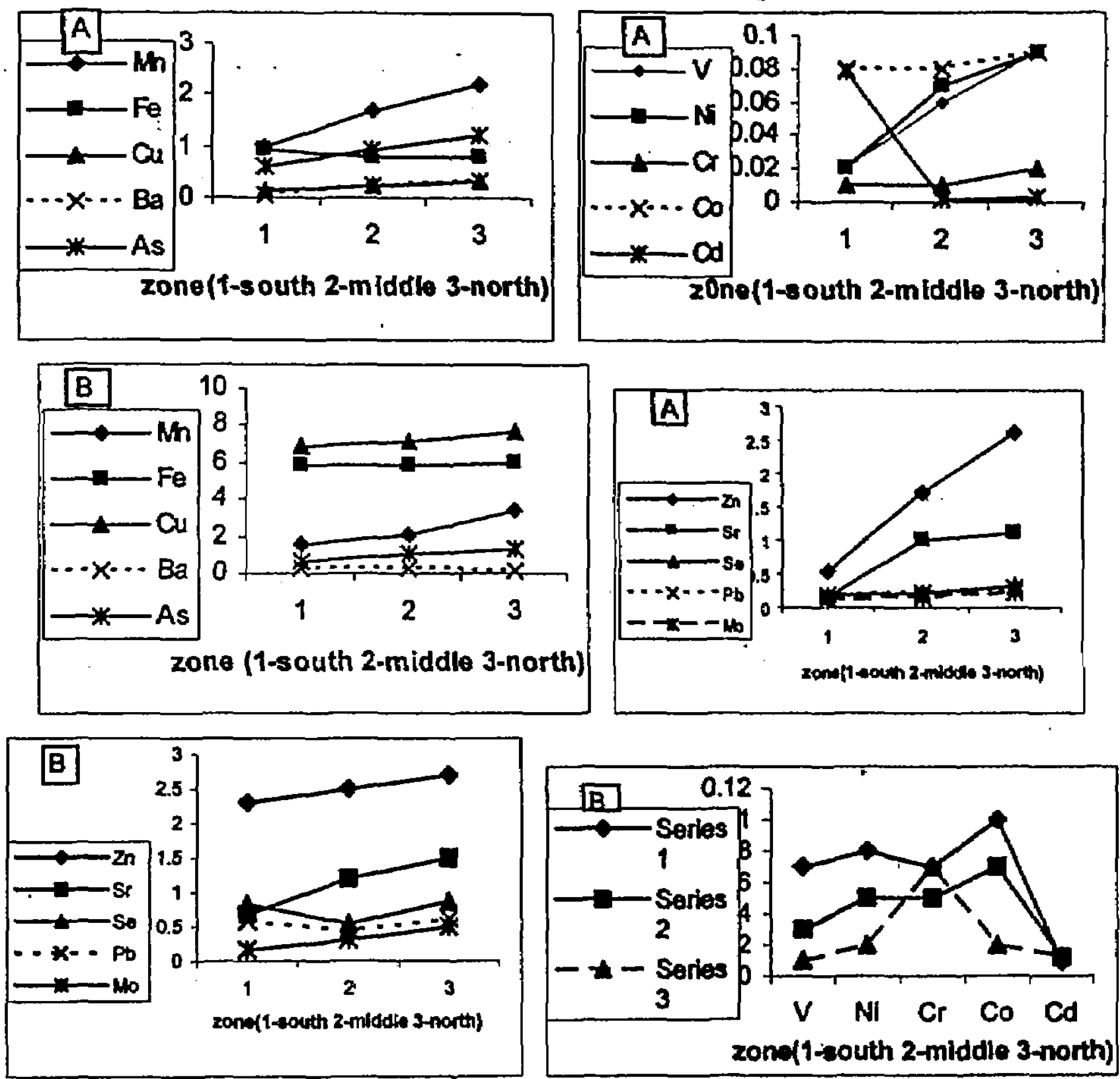
Figure (4): Zonal average distribution of trace metals $\left(\mathrm{ppm} \times 10^{-3}\right)$ in the studied shells of Bellamiya unicolor (gastropod $A=$ adult, $B=$ nepionic).
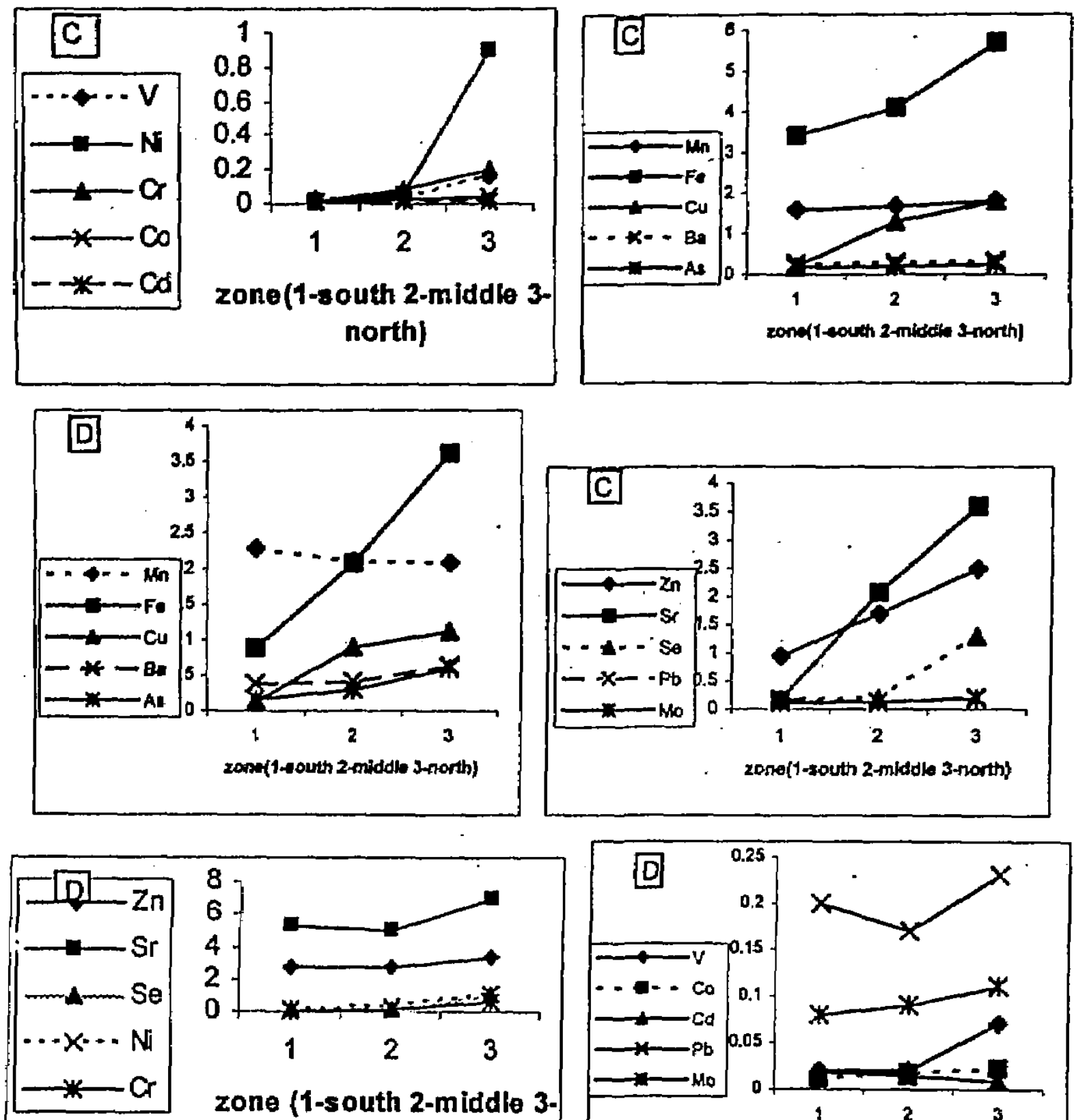

zone (1-south 2-middle 3north)

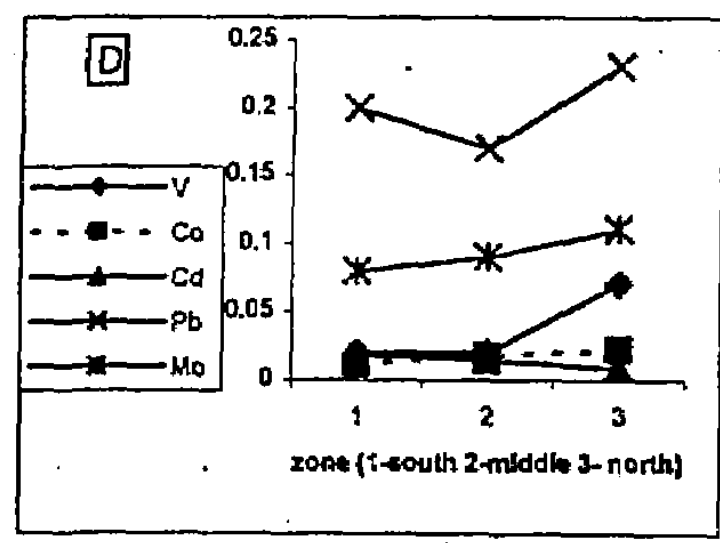




\section{TRACE METALS IN MOLLUSCAN SHELLS FROM DAMIETTA NILE BRANCH SEDIMENTS.}

Figure(5): Zonal average distribution of trace metals ( $\mathrm{ppm}$ and all values $\times 10^{-3}$ ) in the studied shells of bivalve and gastropod from lake Qarun.
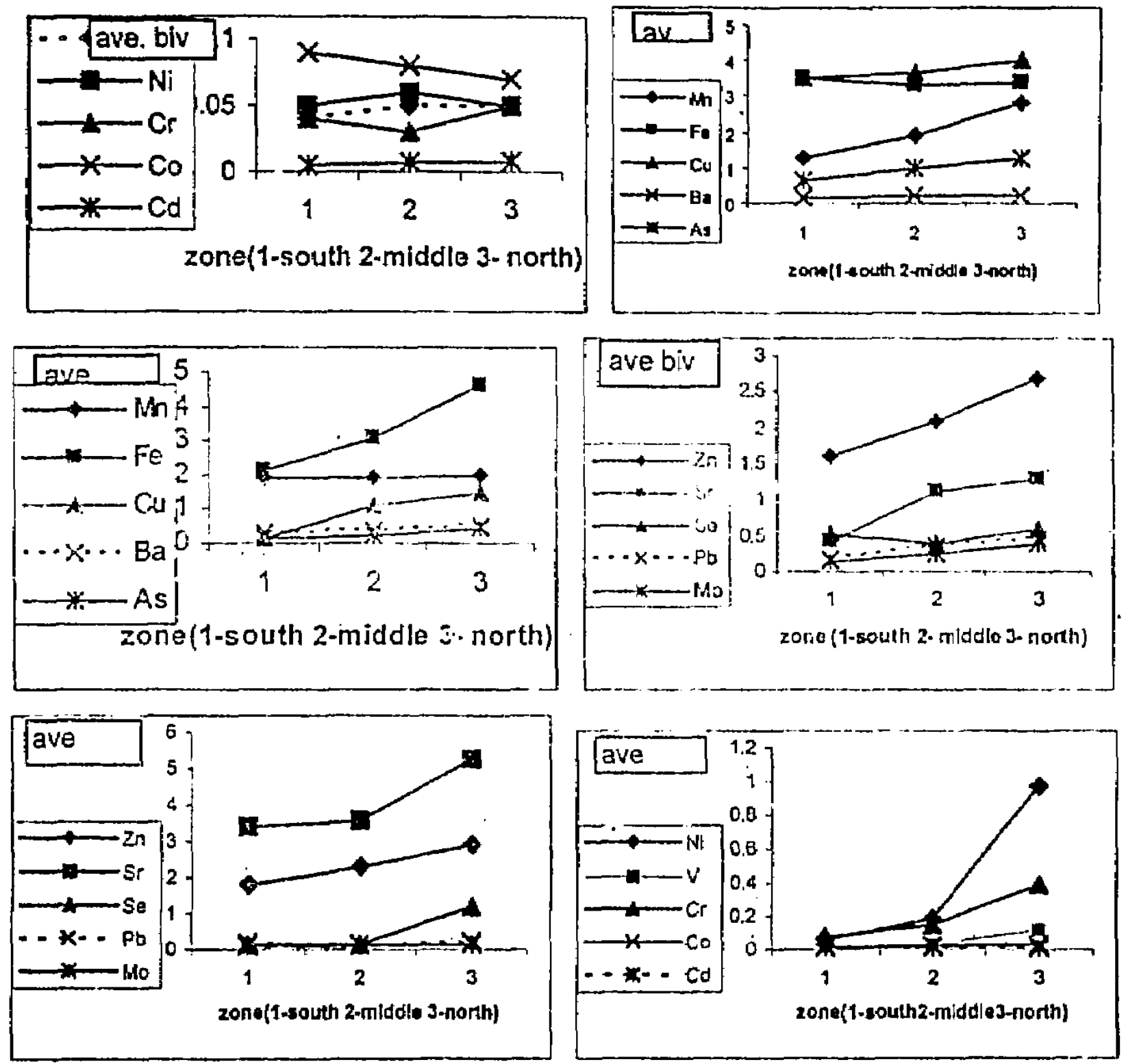